\title{
SOME MINOR AND TRACE ELEMENTS IN ARCHAEAN MARBLES AND METAMORPHOSED SILICO- CARBONATITES FROM THE FISKENÆSSET REGION
}

\author{
H. Bollingberg, A. M. Hopgood and F. Kalsbeek
}

In 1970, A. M. Hopgood found rare concordant marble layers within the gneisses near Frederikshåbs Isblink. At that time, there was considerable discussion among the geologists participating in the mapping of the Fiskenæsset region on the origin of these gneisses. The finding of these marble layers indicated a sedimentary origin for at least some of the gneisses, provided that the marbles themselves were metasediments, and not, for example, meta-carbonatitic lavas. To answer this last question an investigation of some trace elements in these rocks was undertaken. Very fortunately Hopgood also found a few discordant carbonate-rich rocks in the same area so that a direct comparison between the two rock types could be made. The analyses reported in this paper were made by $\mathrm{H}$. Bollingberg in the Spectrographic Laboratory of the Petrological Institute of Copenhagen University. The study was suggested and coordinated by F. Kalsbeek.

\section{Field relationships}

The field relationships of the rocks under consideration have been described by Hopgood (1973): "All the rocks [in this area] have been affected to a greater or lesser extent by amphibolite facies metamorphism and they comprise predominantly dark grey biotite and hornblende gneiss, together with thin anorthosites (mostly brecciated to white agmatites), intercalated striped green and dark grey amphibolite (sometimes garnetiferous), black hornblendites, garnet-kyanite sillimanite gneisses, sillimanite quartzites and pegmatitic pale creamy brown marbles and calc-silicate gneiss and fine-grained leucocratic gneisses. Early discordant layers include hornblendites, amphibolites, peridotites, silico-carbonatites and aplitic rocks.

"The marbles outcrop within gneisses and while close proximity in the field can be demonstrated between the marble and anorthosite at one locality, and amphibolites and ultrabasics outcrop throughout the same general area as the marble, this is not consistently the case and no genetic relationship has been proved between these rock types" . . . "At several localities thin boudinaged bands of diopside which may represent the metamorphosed equivalents of thin marble bands are however, definitely associated with amphibolites. Furthermore, the association of the sillimanite and kyanite bearing rocks with the same amphibolites is certain and in the south-east a single isolated lens of marble outcrops in close proximity to these amphibolites and associated hornblendites."

At the place where the marbles are best developed, the gneisses are fairly clearly banded and within these gneisses both marble bands and layers of calc-silicate gneiss occur in a zone $c .50 \mathrm{~m}$ wide. Marble bands generally do not lie in direct contact with the biotite 
gneiss, but are separated by layers of hornblende calc-silicate gneiss. The latter may also occur interlayered with biotite gneiss without the presence of marble and in places hornblenditic lenses may be associated as well.

Thin marble bands are almost entirely confined to a $5 \mathrm{~m}$ wide zone in which they form layers a few decimetres thick interbanded with white calc-silicate gneiss. Above and below this zone calc-silicate gneiss layers occur regularly, but marble bands are rare. The marble and calc-silicate gneiss are isoclinally folded in two directions at right angles $\left(F_{1}\right.$ and $\left.F_{2}\right)$ and repetition of the layers must therefore almost certainly occur. Nevertheless it seems improbable that all separate marble bands represent a single original layer.

Most of the gneisses in the zone are ordinary, grey, fine-grained biotite-plagioclase gneisses. They may contain concordant, often pinkish, pegmatitic veins and parts of the gneisses themselves may be pinkish in colour. Greyish and pinkish bands often alternate.

Two highly deformed carbonatitic dykes, $c .1 \mathrm{~m}$ wide, have been found in the area; they post-date $F_{1}$ as they cut the foliation associated with the $F_{1}$ folding, but they are themselves cut by thin aplites that are deformed by $F_{2}$ folds. Both dykes have subvertical attitudes and a surprisingly rectilinear outcrop that can be followed for a few hundreds of metres. "But for the complexity of their fabric coupled with the cross-cutting relationships of other intrusions their rectilinearity makes them appear at first sight to be comparatively late igneous features" (Hopgood, op. cit.).

\section{Petrography}

The marbles consist of calcite (only occasional traces of dolomite were found by X-ray diffraction), quartz, plagioclase, \pm microcline, \pm diopside, \pm scapolite, hornblende, actinolitic amphibole and epidote in variable amounts. The plagioclase is relatively sodic $\left(\mathrm{An}_{25-30}\right)$ even where it is in contact with calcite.

The calc-silicate rocks consist of the same minerals but contain only small amounts of calcite; they are sometimes very rich in microcline. Reddish sphene is an important accessory in the marbles and calc-silicate rocks. Zircon, apatite, allanite and opaque minerals occur in small amounts in the calc-silicate gneisses. Complex reaction rims between the different minerals are common. For example, myrmekitic intergrowths of epidote and quartz may surround hornblende and occur often at hornblende-plagioclase contacts. At contacts between microcline and plagioclase, albite rims often surround the more calcic plagioclase.

The gneisses grade from microcline-poor to microcline-rich varieties. They consist of plagioclase, quartz, biotite, \pm microcline, \pm hornblende. Small amounts of epidote occur in most of the samples and calcite is present in several. Apatite, zircon, allanite and small amounts of opaque minerals occur as accessories.

The silico-carbonatites consist mainly of calcite $(40-80 \%)$, greenish brown biotite (10-40\%), quartz (5-15\%) and some alkali-feldspar. Apatite and dark brown-green allanite occur in appreciable amounts (up to several per cent). Opaque minerals, barytes, sphene and some zircon have been found in minor amounts. The rock is very inhomogeneous, containing calcite-rich and calcite-poor portions and quartz-rich veins. Biotite and calcite reach up to $c .1 \mathrm{~mm}$ in size. The biotite locally shows a strong parallel orientation giving the rock in hand specimen a clear schistosity. Elsewhere the rock appears to have an almost isotropic fabric. 
Table 14. Minor and trace elements in marble, gneisses and silico-carbonatite from the Fiskenasset region, compared with average carbonate sediment and average carbonatite

\begin{tabular}{|c|c|c|c|c|c|c|c|c|c|}
\hline \multicolumn{2}{|c|}{$\begin{array}{c}\text { Average carbonate } \\
\text { sediment }\end{array}$} & Marble (6) & $\begin{array}{l}\text { Calc-sili- } \\
\text { cate gneiss } \\
(5)\end{array}$ & $\begin{array}{c}\text { Plagioclase- } \\
\text { gneiss (9) }\end{array}$ & $\begin{array}{l}\text { K-feldspar- } \\
\text { rich gneiss } \\
(8)\end{array}$ & \multicolumn{2}{|r|}{$\begin{array}{c}\text { Silico- } \\
\text { carbonatite (9) }\end{array}$} & \multicolumn{2}{|c|}{$\begin{array}{c}\text { Average } \\
\text { carbonatite }\end{array}$} \\
\hline $\mathrm{Ba}$ & $10(580)$ & $160(80-360)$ & $40(10-70)$ & $125(100-170)$ & $640(70-1180)$ & 10 & $000(4000-40000)$ & 3600 & $\mathrm{Ba}$ \\
\hline $\operatorname{sr}$ & 610 & $820(400-1800)$ & $500(320-580)$ & $300(220-730)$ & $370(230-600)$ & 2 & $700(1500-4000)$ & 3900 & $\mathbf{S r}$ \\
\hline Mn & 1100 & $730(640-810)$ & $650(100-880)$ & $280(<200-420)$ & $140(200-210)$ & & $910(350-2000)$ & 5300 & $\mathrm{Mn}$ \\
\hline $\mathrm{Zr}$ & $19(160)$ & $30(<30-70)$ & $145(80-300)$ & $120(<30-180)$ & $60(<30-115)$ & & $465(190-$ & 1120 & $\mathrm{Zr}$ \\
\hline$Y$ & 30 & $30(20-40)$ & $n \cdot d \cdot-20$ & $\mathrm{n} \cdot \mathrm{d}$ & $\mathrm{n} \cdot \mathrm{d}$. & & $140(<50-220)$ & 96 & $\mathrm{Y}$ \\
\hline $\mathrm{Nb}$ & $0.3(11)$ & $19(18-20)^{3}$ & $21(21-21)^{3}$ & $20^{1}$ & $19(18-20)^{2}$ & & $32(27-39)^{7}$ & 1951 & $\mathrm{Nb}$ \\
\hline La & $\times(92)$ & $75(40-120)^{3}$ & n.d. $-80^{3}$ & n.d. ${ }^{1}$ & $n \cdot d .^{2}$ & & $620(80-1400)$ & 516 & La \\
\hline $\mathrm{Ce}$ & 11.5 & - & - & - & - & & $3301000^{*}$ & 1505 & $\mathrm{Ce}$ \\
\hline $\mathrm{Cr}$ & 11 & n.d. -15 & n.d. -10 & $<10$ & $<10$ & & $80(20-240)$ & 48 & $\mathrm{Cr}$ \\
\hline $\mathrm{Ni}$ & 20 & $7(5-9)^{3}$ & $7(6-8)^{3}$ & $7^{1}$ & $<3^{2}$ & & $50(10-115)^{4}$ & 8 & $\mathrm{Ni}$ \\
\hline
\end{tabular}

Column 1: average carbonate sediment (in brackets average shale) after Turekian \& Wedepohl (1961). x for La Wedepohl (1961). $x$ for La
Columns 2-6: Fiskengsset rocks. The table gives averages and ranges. The number of samples analysed is given between brackets after the rock type. n.d. = not detected; - = not analysed; $<10=$ detected, but concentration too low for accurate determination (to calculate averages in theses cases, it was assumed that half of the detectable amount is present). Where not all samples were analysed, the number of analyses is indicated by a superscript number. ${ }^{*} \mathrm{Ce}$ values demined by John Bailey, Petrological Institute, University of Copenhagen, by X.R.F.
Column 7: average

carbonatite values from Heinrich (1966). All values in $\mathrm{ppm}$. 
Table 15. Distribution of minor and trace elements in the silico-carbonatite minerals

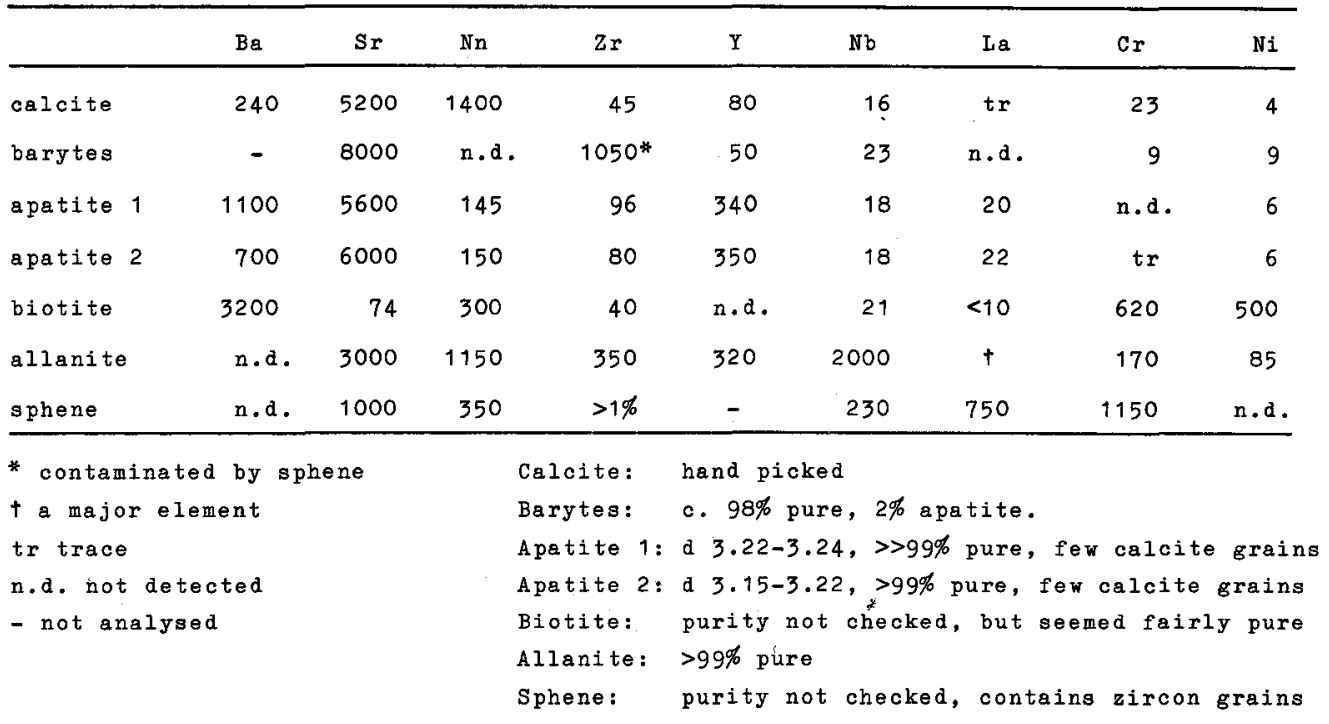

\section{Minor and trace elements}

Samples of the marble, the calc-silicate gneisses, the plagioclase- and K-feldspar-rich gneisses and the silico-carbonatitic dykes were analysed by emission spectrography for several of the elements that characterise rocks of carbonatitic affinity (Table 14).

Rock or mineral powders were mixed with carbon containing $0.02 \% \mathrm{Pd}$ in the proportion $1: 2, \mathrm{Pd}$ serving as internal standard. The spectrochemical analyses were performed on a large Hilger quartz spectrograph in the range of $2400-5000 \AA$. Ilford Chromatic plates were used and measurements of line intensities were made on a Jarrel-Ash microphotometer. Both synthetic and international rock standards were used. Relative standard deviations are in the order of $10 \%$. Detection limits are in the order of $5-20 \mathrm{ppm}$.

The results show that the marble has a trace element composition that compares well with calcareous sediments (Turekian \& Wedepohl, 1961) and with the surrounding gneisses. The carbonatitic dykes, on the contrary, compare well with other carbonatitic rocks, having high contents of $\mathrm{Ba}, \mathrm{Sr}, \mathrm{Zr}$ etc (Heinrich, 1966). Only for $\mathrm{Nb}$ are much lower contents than in average carbonatite found. The distributions of the elements over the different minerals is shown in Table 15.

\section{Conclusions}

The trace element composition shows unequivocally that, whereas the dykes were igneous in derivation, the concordant marbles were sediments in origin. The presence of definite metasediments in the gneisses suggests that some of these may also be of metasedimentary origin. However, it is thought that such gneisses are relatively rare in the Fiskenæsset region (see e.g. Myers, this report). 
Since younger carbonatites characteristically occur in stable continental areas, the presence of carbonatitic rocks in the area is very interesting. If the field evidence is not deceptive and the rocks are in fact very old, their presence might indicate that the crust in this region was already quite thick and intermittantly stable $2800-3000$ m.y. ago.

\section{References}

Heinrich, E. W. 1966: The geology of carbonatites. Chicaco: Rand McNally \& Co.

Hopgood, A. M. 1973: The pre-Ketilidian history of the gneisses north-west of Frederikshåbs Isblink, Fiskenzsset region. Rapp. Grønlands geol. Unders. 51, 54-59.

Turekian, K. K. \& Wedepohl, K. H. 1961: Distribution of the elements in some major units of the Earth's crust. Bull. geol. Soc. Am. 72, 175-191. 